\title{
Mindig útban? - Városias környezetben fennmaradt földikutya-állományok megőrzésének kihívásai Magyarországon
}

\author{
Németh Attila ${ }^{1,2}$, Moldován Orsolya ${ }^{3}$ és Szél László ${ }^{3}$ \\ ${ }^{1}$ Magyar Madártani és Természetvédelmi Egyesület, 1121 Budapest, Költő u. 21. \\ ${ }^{2}$ Magyar Természettudományi Múzeum, 1088 Budapest, Baross u. 13. \\ ${ }^{3}$ Hortobágyi Nemzeti Park Igazgatóság, 4024 Debrecen, Sumen u. 2 \\ E-mail: dr.attila.nemeth@gmail.com
}

\begin{abstract}
Összefoglaló: A nyugati földikutyák (Nannospalax (superspecies leucodon)) Magyarország legveszélyeztetettebb emlősei közé tartoznak. Az elmúlt fél évszázad során drámai mértékủ és gyors ütemú állománycsökkenésen estek át, ezért elterjedésük, fennmaradt állományaik száma pontosan nem ismert. Még létező populációik felkutatása a konzervációbiológia aktuális feladata. Az előkerülő újabb töredékállományok azonban gyakran okoznak a természetvédelem számára szokatlan, nehezen kezelhető helyzeteket, mivel jellemzően nem védett területeken, hanem beruházások, fejlesztések helyszínein, építési vagy mezőgazdasági hasznosítás alatt álló területeken találhatóak. Bemutatjuk az utóbbi évtizedben megtalált állományokat, valamint azokat a problémákat, melyeket ezeknek az állományoknak a megőrzése okoz. Az eddigi erőfeszítések, az alkalmazott megoldások és azok tanulságai hozzájárulhatnak más fajok, illetve hasonlóan kényes helyzetek természetvédelmi szempontból megfelelő kezeléséhez is.
\end{abstract}

Kulcsszavak: Nannospalax (superspecies leucodon), elterjedés-térképezés, állományfelmérés, monitorozás, élőhelyigény

\section{Bevezetés}

Az utóbbi évszázadok során a száraz, füves élőhelyek Európa-szerte drámai mértékben szorultak vissza (Bakker 1989, Poschlod \& Bonn 1998). A Kárpát-medence sztyepp jellegü élőhelyei is a történelem előtti idők óta szenvednek az emberi tevékenység természeti környezetre gyakorolt hatásaitól (Németh et al. 2017). Ez az érzékeny ökoszisztéma azonban nem csupán a távoli múltban szenvedett el komoly veszteségeket, a száraz füves élőhelyek a történelemi időkben, de különösen a legutóbbi száz év során mind jobban összezsugorodtak Magyarországon (Bíró et al. 2018). Az élőhelyvesztés a biológiai sokféleség nagymértékủ csökkenését vonja maga után (Hanski 2011, Newbold et al. 2015). Jó néhány, a füves élőhe- 
lyekhez kötődő és egy-két évszázada még gyakorinak számító állatfaj pusztult ki vagy ritkult meg drámai módon (Rakonczay 1989). A Kárpát-medencei száraz, füves élőhelyek jellegzetes emlősközösségének egyik utolsó, máig fennmaradt, erősen specializált tagja a nyugati földikutya (Nannospalax (superspecies leucodon) Nordmann, 1840) (Horváth et al. 2007, Németh et al. 2018). A földikutyák a talajlakó életmódhoz szélsőségesen alkalmazkodott rágcsálók (Topachevskii 1969, Vidacs et al. 2013). Sajátos testfelépítésük és különös életmódjuk a hazai emlösfauna egyedülálló tagjává teszik őket (Vásárhelyi 1926) csakúgy, mint rendhagyó evolúciós történetük (Németh \& Csorba 2014). Ugyanakkor a fokozottan védett földikutyák Magyarország legveszélyeztetettebb emlősei közé tartoznak. Bár e talajlakó rágcsálók egykor széles körben elterjedtek voltak az ország területén, élőhelyeik átalakításának és megszünésének következtében kritikus helyzetbe kerültek (Németh et al. 2013a). Mivel azonban a földikutyák egyetlen évtized leforgása alatt váltak rettegett mezőgazdasági kártevőből ritka és veszélyeztetett állattá (Sterbetz 2002), ezért visszaszorulásuk története egyáltalán nem ismert. Ahogyan az sem, hogy esetleg hol találtak menedékekre abban az agrárterületekuralta kultúrtájban, amely egykori élőhelyükön jött létre. Így aktuális hazai elterjedésük, fennmaradt állományaik száma ma sem ismert pontosan (Németh et al. 2010). Ugyanakkor a még létező populációk felkutatása a természetvédelmi biológia egyik legaktuálisabb feladata (Németh et al. 2013a).

A 20. század második felének túlnyomó részében csupán egyetlen földikutyaállomány volt ismert Magyarországon, a Hajdúbagosi Földikutya Rezervátumban élő. Az 1990-es évekre ez két további, a Debrecen-Józsán (Dudás \& Lánszky 1988) és a hajdúhadházi Liget-legelő nevü honvédségi területen (Horváth 2001) élő populáció, megtalálásával egészült ki. A 2000-es évek elején végzett, az Alföld egészére kiterjedő felmérés során két Békés megyei területen, a Tompapusztai löszgyepen és a Battonya területén lévő Gulyagyepen is valószínüsítették földikutya-állomány létezését (Horváth \& Vadnay 2006). Így a 2000-es évek elején öt helyen volt ismert földikutyák előfordulása Magyarországon.

Azonban az ország különböző vidékeiről időről-időre előkerülnek olyan anekdotikus történetek, melyek arra utalhatnak, hogy a Magyarországon ténylegesen létező földikutya-populációk száma esetleg magasabb lehet aktuálisan igazoltnál. A földikutya-állományok valós számának és a földikutyák pontos hazai elterjedésének megismerése ugyanakkor alapjaiban határozzák meg az egyes hazai földikutya-fajokkal kapcsolatos természetvédelmi stratégiákat. Ezért a 2000-es évek derekán kezdődött, a Magyar Természettudományi Múzeum irányításával zajló, átfogó földikutya-kutatások során ezeknek a kérdéseknek a tisztázása mindig is az egyik legfontosabb feladat volt, folyamatosan zajlott a potenciális földikutya előfordulási helyek módszeres ellenőrzése. 
Cikkünkben bemutatjuk a 2005 óta Magyarországon azonosított, korábban a szakemberek számára ismeretlen földikutya-állományokat. Összefoglaljuk jellemzőiket, és megvitatjuk sajátságaikat, melyek olykor jelentősen különböznek a korábban ismert állományok tulajdonságaitól. Részletesen megtárgyaljuk, hogy milyen nehézségeket okoz az új állományok megőrzése. Áttekintjük és értékeljük megőrzésük érdekében tett természetvédelmi erőfeszítéseket és azok eredményeit. A következtetések levonása után pedig javaslatokat fogalmazunk meg a gyakorlati természetvédelem szakemberei számára.

\section{Anyag és módszer}

A bemutatott felmérések és vizsgálatok elvégzésére a mindenkori természetvédelmi hatóságok (aktuálisan a Pest Megyei Kormányhivatal Környezet és Természetvédelmi Főosztálya) által kibocsátott kutatási engedélyek (14/1840-3/2008, 14/01439-9/2012, OKTF-KP/6903-21/2015, PE-KTF/5215-22/2017) nyújtottak lehetőséget.

\section{Földikutya-állományok azonositása}

$\mathrm{Az}$ ismeretlen földikutya-populációk felkutatása során egyrészt a szakirodalomból ismert korábbi előfordulási helyek környezetében még megmaradt gyepek bejárása történt meg, másrészt pedig a földikutya jelenlétére utaló, ismertté vált jelzések, történetek ellenőrzésére került sor.

A földikutyák előfordulásáról egy adott potenciális élőhelyen a túrások árulkodnak, minthogy a földikutyatúrások az egyetlen - a felszínen is észlelhető nyomai e talajlakó rágcsálók jelenlétének (Vidacs et al. 2013). Azonban más, talajlakó vagy akár részben a felszínen élö állatok, mint amilyenek a közönséges vakond (Talpa europaea Linnaeus, 1758) vagy a közönséges kószapocok (Arvicola amphibius Linnaeus, 1758) is hasonló túrásokat hozhatnak létre (Vásárhelyi 1930). Ugyanakkor túrás- és járatmorfológiai alapon lehetséges az egyes fajok túrásainak, illetve járatrendszerének megkülönböztetése (Boldog 2010, Németh 2011). A földikutyák túrásaira jellemző, hogy általában (i.) nagyméretủek, (ii.) a szomszédos túrások egymástól mérhető távolsága nagy $(1,5-2 \mathrm{~m})$, (iii.) a túrások térbeli elrendeződése szabályos, közel egyenes vonal mentén sorakoznak, (iv.) a túrások tetején megfigyelhető ún. földhurkák átméröje nagy $(6-9 \mathrm{~cm}),(\mathrm{v}$.) továbbá a földikutyatúrásokban a talajjal keveredve megfigyelhetőek rövid gyökérdarabok, melyek vége hegyes szögben van leharapva (Boldogh 2010, Németh 2011). A földikutyák járataira jellemző, hogy rendszerint (i.) nehéz megtalálni őket a túrás alatt, (ii.) a járat jellemzően nem a túrás közepe alatt található, hanem 
a szélénél, érintő mentén halad, (iii.) a járatok kerekek, nagyméretüek ( $>6 \mathrm{~cm})$, tapinthatóan kemény falúak és nem lógnak be gyökerek a járatba, (iv.) a járatok egyenes lefutásúak, nem kanyargóak, valamint (v.) megfelelő talajtani jellemzők (kötött, agyagos és nedves talajok) esetén a járatok falában láthatóak a földikutya orrának lenyomatai (Németh 2011). Az előbb felsorolt bélyegek együttes megléte igazolni tudja, hogy földikutya fordul elő a vizsgált területen.

Az egyedszámbecslés és a monitorozás

Az állománybecslések alapjául szolgáló felmérésekre a tavaszi, illetve az őszi aktivitási időszakokban került sor. Mivel a földikutyák aktivitását az adott év időjárása erősen befolyásolja, a tavaszi felmérések tél végétől (február) májusig terjedő időszakban zajlottak. Az őszi felmérésekre szeptember és november között került sor. Egy adott aktivitási időszakon belül a populáció egyedszámának minél pontosabb becslése érdekében egyazon élőhelyen legalább két állományfelmérés zajlott. Az állományok egyedszámának meghatározása a földikutya-élőhelyek térképére ráhelyezett négyzetrácsháló segítségével, vonalas felmérési módszer szerint történt. A friss túrások pozíciója kézi GPS készülékkel (Garmin Oregon 600) került rögzítésre. Kizárólag a friss túrások rögzítésére került sor, az időjárás által elsimított, ellapult túrások nem kerültek felvételre. Annak érdekében, hogy minden túrás csak egyszer kerüljön rögzítésre, a már felvett pozíciójú halmokat elsimítottuk. Mindez abban is segített, hogy az ugyanazon a helyen történő újbóli rátúrások is észlelhetőek legyenek. A földikutyák magányos életmódot folytató, territóriumukat elszántan védelmező állatok (Vásárhelyi 1926), ezért az egymás szoros közelségében levő túrásokat egy egyedtől származó életnyomnak tekintettük. Az adatok térinformatikai feldolgozása és értékelése Quantum GIS program segítségével történt (QGIS Development Team 2013).

\section{Tájtörténeti vizsgálatok}

Az eredmények és tapasztalatok helyes és megalapozott értékelése érdekében a földikutya-élőhelyek és áttelepítési helyszínek adottságairól, jellemzőiről minél teljesebb képet igyekeztünk nyerni. Az élőhelyek és környezetük tájtörténetének feltárása az Első (1783-as), a Második (1858-as), és a Harmadik (1881-es) Katonai Felmérés térképlapjai (http1,2,3), valamint a II. világháború idején (1941) készült katonai térképezések (http4) segítségével történt. Az elmúlt fél évszázad során (1959-2007) az élőhelyeken zajlott folyamatokat a Lechner Nonprofit Kft. légifilmtárában található felvételek (http5) segítettek nyomon követni. A legutóbbi két évtized változásait a Google Föld program korábbi térképeinek („,történelmi térképek”) vizsgálata tette lehetővé (Google Earth Pro, ver. 7.3.2.5776). A térképfeldolgozások során a Quantum GIS programot használtuk (QGIS Development Team 2013). 


\section{Eredmények}

\section{5 után azonositott földikutya-állományok}

Az alábbi, korábban ismeretlen állományokat sikerült 2005 óta azonosítani (1. ábra):

- 1. Kelebia: 2008 márciusában három egymástól izolált gyepfragmentumon sikerült földikutyát fogni (Németh et al. 2013b). Az állomány Kelebia és Ásotthalom külterületén, a szerb-magyar határ közelében él, utak, erdőfoltok és müvelt területek által elválasztott, jellemzően erősen degradált, homoktalajú gyepfragmentumokon. A becsült egyedszám körülbelül 100-150 egyed (Németh et al. 2013a).

- 2. Mezötúr: 2008 júliusában a város belterületén, egy ipari telephelyen a felszínen mozgó, élő földikutyát találtak. A populáció még beépítetlen, de hasznosításra, ingatlanfejlesztésre szánt üres telkeken él, két, egymástól izolált gyepfragmentumon és egy széles mezsgyén. Az élőhelyeket jellegtelen növényzetü mezofil gyepek borították. 2019 tavaszán további, az ismert előfordulásokhoz hasonló adottságú területek ellenőrzésére is sor került. Két további helyszínen sikerült megállapítani a földikutya jelenlétét: egy, a városon belül fekvő gyepfragmentumon, valamint a városhatáron kívül található mezsgyén és a mellette fekvő nem mủvelt téglagyár területén is. Ez utóbbi terület állománya minden előzetes várakozásnál nagyobbnak bizonyult, így Mezőtúron összesen mintegy 200 példány földikutya jelenlétét sikerült igazolni.

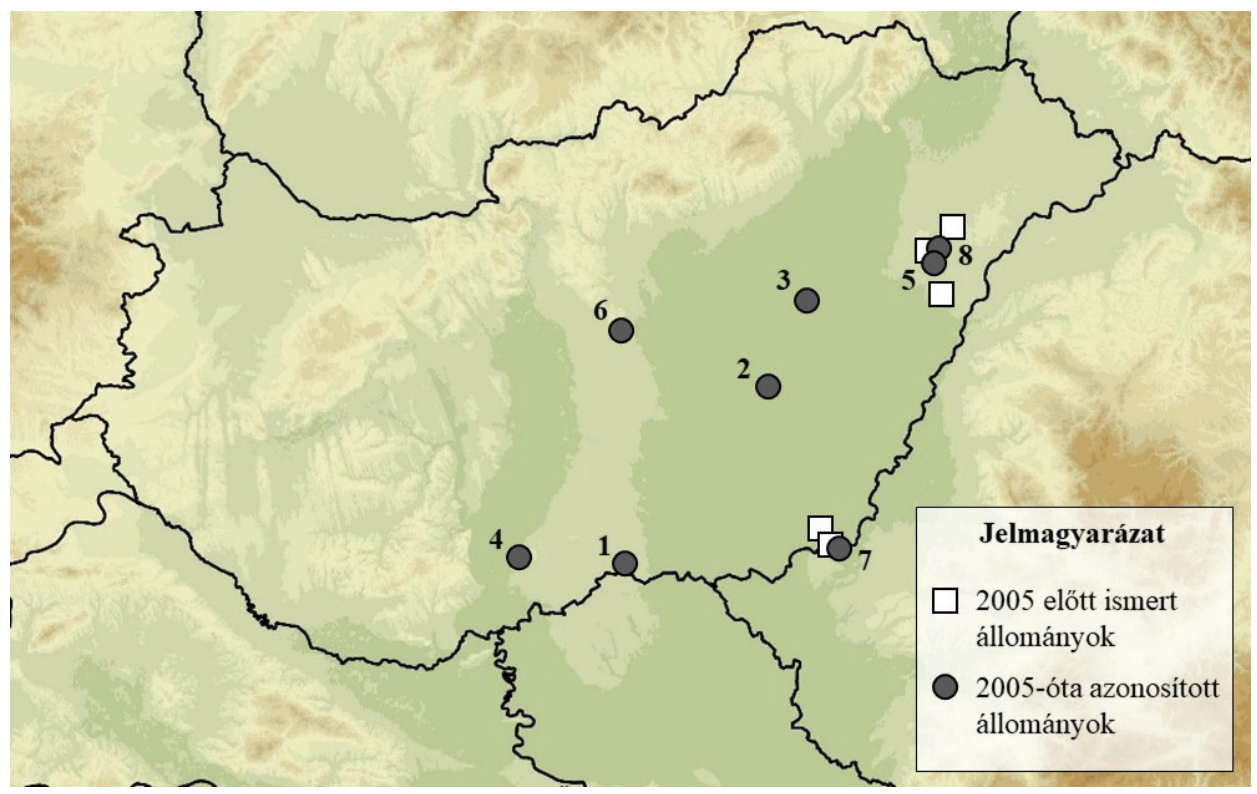

1. ábra: Az ismert földikutya-előfordulási helyek Magyarországon. A 2005 óta azonosított állományok számozása megfelel a szövegben olvashatónak. 
- 3. Kunmadaras: 2008 júliusában a Kunmadaras közelében fekvő egykori szovjet légibázis területén földikutyára utaló túrásnyomokat lehetett megfigyelni. A közvetett bizonyítékok alapján (táplálékraktár, orrlenyomatok a megbontott járatok falain) valószínüsíthető volt a földikutya előfordulása a területen, noha bizonyító példányt csak 2010 tavaszán sikerült fogni. Az élőhelyen a felmérések szerint biztosan nem több, mint 10 földikutya-egyed élhet, három, egymástól betonutakkal elzárt, apró gyepfragmentumon.

- 4. Baja: 2013 tavaszán lakossági jelzés alapján merült fel, hogy Baja város szélén, egy korábbi honvédségi lötér területén földikutyák élhetnek. A terület ellenőrzése során sikerült három eleven földikutyát befogni, a későbbi vizsgálatok és állományfelmérések alapján pedig kiderült, hogy az ország második legnagyobb eddig ismert földikutya-populációját sikerült megtalálni (Csorba et al. 2015). Az állományfelmérések szerint több mint 300 egyed él az egyéb jelentős természeti értékeket is örző, homoktalajú területen.

- 5. Debrecen: 2014 őszén a város északi szélén (a Nyulas nevü részen), egy autószalon mögötti lucernatáblában földikutyatúrásokat azonosítottak. A túrások és megbontott járatrendszerek morfológiai vizsgálata alapján egyértelmű volt, hogy földikutyák élnek a területen. Az első bizonyító példány megfogására 2015 őszén került sor, a felmérések alapján a populáció nagysága 50-60 egyed.Az előbbi élőhelyet nyugatról határoló, magas töltésen futó vasút túloldalán, a vasút és a Tócó-patak közötti területen változatos szántóföldi kultúrák voltak, melyek korábban nem biztosítottak életfeltételeket földikutyák számára. Azonban 2018ban felmerült, hogy az előző évben a területre vetett lucernában is megtalálhatóak földikutyák. A felmérések során egy mintegy 10 példányból álló kis állomány előfordulása nyert igazolást.

- 6. Albertirsa: 2017 tavaszán, Albertirsa szélén, felszínen mozgó földikutyaegyedet figyeltek meg. A megtalált földikutya-populáció váratlan meglepetést okozott, mivel Pest megyéből több mint száz éve (1905 óta) nem volt ismert előfordulási adat (Németh et al. 2009). A Gerje-patak mentén két természetes gyepen, és az azok közelében fekvő parlagokon és üres telkeken mintegy 100 példány él.

- 7. Battonya: 2018 tavaszán végzett terepbejárások során Battonya területén öszszesen négy helyen sikerült földikutyákat találni. Az ezredforduló táján is ismert Gulyagyep mellett, az annak közelében fekvő temető területén, valamint egy mezőgazdasági géptelepen is élnek földikutyák. A géptelep és a Gulyagyep között található elnéptelenedő városrészből ismert a legtöbb földikutyákkal kapcsolatos lakossági beszámoló (Csathó A. pers. comm.), ami alapján valószínüsíthető, hogy e terület kertjeiben is előfordulnak földikutyák, összeköttetést biztosítva az egymástól távolabb fekvő élőhelyek között. A negyedik élőhelyfolt az előbbiektől távolabb, a város délkeleti szélén, a tornyai határátkelő felé vezető út mellett fekszik. 
- 8. Debrecen-Józsa: 2018 öszén érkezett jelzés arról, hogy a földikutya-élőhelyként ismert, a Tócó-patak mellett elhelyezkedő helyi védett, Natura 2000 besorolású terület keleti szomszédságában, már felparcellázott, közmüvesített építési telkeken, a fokozottan védett ürge (Spermophilus citellus Linnaeus, 1766) egy kisebb állománya található. A jelzés ellenőrzése során derült fény arra, hogy 3-4 példány földikutya is él a még beépítetlen telkeken. Ezeket az állatokat a védett területen lévő állománytól mindössze a vasúti sín és az azt kísérő fasor, ill. bozótos választja el.

\section{Veszélyeztetö tényezök}

A feltárt új földikutya-állományok számára az élőhelyvesztés a legjelentősebb veszélyforrás, hiszen folyamatos a gazdasági és társadalmi igény a „kihasználatlan”, „üres” területek hasznosítására. Néhány esetben ez a mezőgazdasági hasznosítás (müvelésbe vonás) veszélyét jelenti. Az élöhely egészére kiterjedő, egyidőben végrehajtott szántás a teljes populáció pusztulását okozhatja. A legtöbb esetben azonban egyértelmủen a beépítés a legtipikusabb oka a földikutya-élőhelyek felszámolására irányuló törekvéseknek. Mivel ezek az élőhelyek legtöbbször semmilyen védelemben nem részesülnek, így akár egyik napról a másikra teljes földikutya-populációk semmisülhetnek meg.

Komoly fenyegetést jelentenek azok a veszélyeztető tényezők is, melyeket összefoglaló néven spontán kedvezőtlen folyamatoknak nevezhetünk. Mivel a városias közegben fennmaradt földikutya-élőhelyek jellemzően nem állami tulajdonban és nem nemzeti parki vagyonkezelésben állnak, ezért az állami természetvédelem szerveinek kevés valódi ráhatása van arra, hogy az élőhelyeken a földikutyák számára kedvező folyamatok legyenek a meghatározók. A kívánatos kezelések elmaradásának következtében spontán cserjésedés, valamint özöngyomok terjedése következhet be. Ezek eredményeként a földikutyák számára táplálékot jelentő lágyszárúak visszaszorulhatnak, ami jelentős táplálékbázis-vesztéssel járhat. Ezek a folyamatok különböző mértékben, de valamennyi, az utóbbi időben megtalált földikutya-élőhelyen megfigyelhetők. Bár a földikutyák számára a legeltetés ideálisabb a kaszálásnál, az utóbbi időkben azonosított földikutyaélőhelyeket legfeljebb kaszálással kezelik. Hasonló problémák tapasztalhatók a lucernásokban élő földikutyák esetében, ahol a lucerna évenkénti kezelésére, illetve betakarítására (kaszálásra) nehéz kötelezni a terület használóit. A spontán kedvezőtlen folyamatok kategóriába sorolható veszélyforrások egy további csoportját jelentik a szélsőséges időjárási események, a globális klímaváltozás és a genetikai leromlás jelentette veszélyek is. Bár e folyamatok minden földikutya-állományt egyformán érintenek, a városias közegben fennmaradt, kisebb kiterjedésü és rendszerint degradált állapotú élőhelyek kevésbé képesek védelmet nyújtani a rajtuk 
élő egyedeknek. A városias környezetben fennmaradt állományokra általában alacsonyabb egyedszám jellemző, emiatt jelentkezhet a genetikai leromlás jelensége is.

A veszélyeztető tényezők harmadik nagy csoportját a fokozódó emberi jelenlét okozta problémák jelentik, mely tényezők pontosan az emberi települések közelében a legjelentősebbek. Ilyen például az illegális hulladéklerakás, ami több, az utóbbi időben megtalált földikutya-élőhelyen gondot jelent. Bár manapság szerencsére egyre kevésbé jellemző, de meg kell említeni a közvetlen emberi pusztítást is. Mindez a faj fokozottan védett státusza ellenére is előfordulhat, a töredékállományokban pedig egy-egy egyed elvesztése is komoly veszteségnek számíthat. Az emberhez köthető további veszélyforrás a háziállatként tartott kutyák és macskák okozta zavarás, pusztítás. Az utóbbi években mind több megfigyelés igazolja, milyen jelentős mértékü az eredeti élőhelyükről kiszoruló, fiatal földikutyákhoz köthető felszíni vándorlás. A felszínen vándorló fiatalok körében óriási pusztítást végezhetnek a településeken élő kutyák és macskák csakúgy, mint például az urbanizálódott varjúfélék (Németh et al. 2016). A földikutyák számára átjárhatatlan barrierek (utak, parkolók, lakóövezetek) szinte teljesen ellehetetlenítik a töredékállományok közötti génáramlást, így a fragmentáció és az izoláció a belterületen éló populációk esetében komoly kockázatot jelent a hosszú távú fennmaradás szempontjából.

\section{Diszkusszió}

\section{5 után azonositott földikutya-állományok jellemzöi}

2005-ben, a Magyar Természettudományi Múzeum által koordinált földikutyakutatások kezdetekor, Magyarország területén öt helyen (Hajdúbagos, DebrecenJózsa, Hajdúhadház, Tompapuszta és Battonya) volt ismert földikutyák jelenléte. Ezek az állományok jellemzően a természetvédelem által ismert, természetvédelmi szempontból értékes (védett vagy védelemre tervezett) helyeken élnek, ahol a földikutyákon kívül is számos más, kiemelkedő jelentőségü természeti érték található. Ezzel szemben a később megtalált állományok többsége olyan helyeken került elö, melyeket az állami természetvédelem alapvetően nem tartott számon. Kisebb részük kiemelkedő természeti értékekkel bíró, ám mindaddig alaposan nem vizsgált területeken bukkant elö, de a megtalált állományok nagyobb része degradált területeken él. Ez utóbbi területek épp ezért jellemzően nem védettek, nem Natura 2000 besorolásúak, és védelemre sem voltak tervezve. 


\section{Földikutyák városias környezetben}

A földikutyákat korábban, mint az érintetlen füves élőhelyek szélsőségesen specializált kisemlősét ismertük (Horváth et al. 2007). Az utóbbi években megtalált állományok jó része ugyanakkor nehezen illeszthető bele ebbe a képbe, ami magyarázatul is szolgálhat arra, miért maradhattak oly sokáig rejtve a természetvédelmi szakemberek előtt. Bár a földikutyák életmódjukat illetően valóban szélsőségesen specialisták (Vidacs et al. 2013), de zavartalan élőhely és kellő mennyiségü táplálék esetén a száraz, füves élőhelyek sokféle típusán képesek túlélni. Az említett viszonyok - a rendszeres talajbolygatással nem járó területhasználat, vízhatásoktól mentes élőhelyek - a múlt század derekán a tájhasználatban, illetve a mezőgazdasági termelés szerkezetében bekövetkezö változások, valamint a rendszerváltás utáni gazdasági változások nyomán nagyon sok esetben éppen a települések közvetlen közelében maradtak csak fenn. Ezt a lehetőséget pedig, a jelek szerint, a földikutyák sok esetben meg is ragadták.

Mindez felveti a kérdést, hogy a városias élőhelyek valamiféle refúgiumot jelentenek, és korábban jelentős földikutya-állományok utolsó menedékét képviselik, vagy ökológiai csapdaként a biztos pusztulásba csalták a földikutyákat?

A tájtörténeti vizsgálatok alapján a 18 . század végétől folyamatosan csökkent a földikutyák számára alkalmas élőhelyek kiterjedése. A folyamat az utóbbi száz évben drámaian felgyorsult. Az eredeti élőhelyekből sok esetben csupán a települések közelében fekvő, zsebkendőnyi foltok maradtak fenn napjainkig. Egy adott földrajzi régióban ugyanakkor ezek az élöhelyek - drasztikusan lecsökkent egyedszám mellett, de - képesek voltak a korábbi, jelentős földikutya-állományok fennmaradását biztosítani, és így genetikai értelemben is megőrizték a populációkat. Jól példázzák ezt Mezőtúr vagy Battonya belterületi élőhelyei, ahol a kiemelkedő termőképességü, magas aranykorona-értékü talajokkal rendelkező területeken a szántóföldi termelés mind intenzívebbé válásával párhuzamosan a földikutyák életfeltételei szinte teljesen megszüntek. Ugyanakkor a belterületen túlélő állományok mindkét régióban biztosították a földikutyák fennmaradását.

Annak kimenete, hogy ezek a legtöbbször kis egyedszámú, lakott területek szomszédságában fekvő földikutya-állományok végül fenn fognak-e maradni, vagy csupán néhány évtizeddel elodázták a földikutyák egy-egy térségből történő kihalását, az a hazai természetvédelmen (is) múlik. Az esetek döntő többségében ezek az élőhelyek eddig valóban refúgiumként szolgáltak.

Ugyanakkor a városi környezetben megtalálható földikutya-élöhelyek között valódi ökológiai csapdát is találunk. A kis kiterjedésü, ezért kevés egyed eltartására képes, és így túltelített élőhelyek esetében komoly probléma, hogy az onnan kiszoruló és ezért felszíni vándorlásba kezdő fiatal egyedek (Heth 1991, Németh et al. 2016) az eredeti élőhelyükhöz legközelebbi alkalmasnak látszó gyepterüle- 
ten telepednek meg. A Debrecen-Józsán építési telkeken megtalált állomány jó példa erre. A korábbi fatelep elhagyott és elhanyagolt területét a 2000 -es évek derekán felvásárolták, rendbe tették és építési telkekké alakították. Ám a 2000es évek közepének gazdasági válsága miatt a tervezett beruházások elmaradtak. A telkek legalább tíz évig háborítatlanul álltak és közben potenciális földikutyaélőhelyekké váltak. Azonban 2018-ban megkezdődtek a beruházások. A megtalált földikutya-állomány egy új házakból álló, kész lakópark még beépítetlen részein, foghíjtelkeken került elő. Ezek a gyeppel borított, a beépült telkek közé ékelödő területek csapdaként müködhetnek a szomszédos védett területről kiszoruló, és ezért a felszínen vándorolva új élőhelyet kereső fiatal egyedek számára. A betelepülő földikutyák ugyanis nem képesek valódi populációt kialakítani a területen, sokkal inkább jellemző, hogy a zavarások miatt időről időre eltünnek (elpusztulnak vagy elvándorolnak), és helyükön jelennek meg a védett területröl minden évben kiszoruló új, fiatal példányok.

\section{A városias környezetben fennmaradt földikutya-állományok típusai}

A települések közelében megtalált földikutya-állományokat két markánsan különböző csoportba lehet sorolni. A legtöbb állomány élőhelye a természetes élőhelyekhez hasonlít, csak éppen egy település közvetlen közelében, vagy akár annak belterületén helyezkedik el, ezeket fragmentált természetközeli élőhelyfoltoknak tekinthetjük.

Ezzel szemben a mezőgazdasági kultúrában található földikutya-állományok egy teljesen más típust képviselnek. Élőhelyeik nem csupán urbanizált környezetben helyezkednek el, de maguk is antropogén eredetủek. Ember által létrehozott, fenntartott és szabályozott, szélsőségesen fajszegény, ám ugyanakkor táplálékban rendkívül gazdag területek. Az élőhelyeket uraló folyamatokat (például a növényzet megújulásának módját, térbeli- és időbeli ütemét, valamint mértékét) az emberi tevékenység irányítja.

A két élőhelytípus jellemzői alapvetően befolyásolják az állományok népességét, az egyedek testméretét és viselkedését. Míg a legtöbb városi környezetben fennmaradt populációban az egyedek viselkedése alapvetően megegyezik a korábban ismert, természetes élőhelyekről származó egyedeknél megfigyeltekkel, addig a lucernaföldek földikutya-állományaiban élő egyedek viselkedése nagyon eltérő, olyan jellegzetességekkel, melyek ezidáig ismeretlenek voltak a Kárpátmedencei földikutyák esetében.

A természetes élőhelyeken ideális esetben tapasztalható hektáronkénti 2-3 egyed előfordulásával szemben, a mezőgazdasági területeken az egyedsürüség szokatlanul magas, a hektáronkénti 10 egyedet is meghaladja. Mindez leginkább a lucernaföldek természetes élőhelyekkel szemben fennálló nagyfokú táplálékbőségével magyarázható. Az egyedek járatrendszere is eltér a természetes élőhelyeken 
megszokottól: rövid járatszakaszokból álló, sürün elágazó járatrendszereket találunk. Mivel az élőhely talaját sürűn behálózzák a lucerna tápláló, vastag gyökerei, az egyedeknek a táplálék felkutatásához nincs szükségük hosszú, egyenes járatokra. Ez magyarázhatja a földikutyákra más élőhelyeken egyáltalán nem jellemző, sokkal inkább a vakondéra emlékeztető járatrendszereket. A járatokban szokatlanul nagyméretü földikutyák élnek. A 2005 óta a Kárpát-medencében megfogott öt legnagyobb testtömegü földikutyából négy a debreceni lucernaföldön került kézre. A lucernaföldi példányok testtömege akár 100 grammal (35-50\%-kal) is meghaladhatja a térségben élő földikutyákra egyébként jellemző értéket. A megfogott példányokon feltűnően gyakoriak voltak korábbi sebesülések gyógyult nyomai. Bár a nagy hímeken általában láthatók korábbi csatározásokból származó hegek, a Debrecenben fogott példányok esetében egészen extrém eseteket lehetett megfigyelni. Az egyik hatalmas hímnek például az ágyéktáján voltak gyógyult sebei, valamint hiányzott az egyik tesztisze. A magasabb egyedsürüség az agreszszivitás növekedéséhez vezethet (Calhoun 1962, Judge \& De Waal 1997, Knell 2009), ugyanakkor a betegségeknek és a parazitáknak is kedvez (Dobson \& Hudson 1986, Ives 1992). Nagyon sok megfogott példányon voltak megfigyelhetőek szőr nélküli kopasz foltok, vagy ezek gyógyuló nyomai. Ilyet más állományokban korábban nem tapasztaltunk. Az állatorvosi vizsgálat megerősítette az élősködő atkák (Listophorus sp.) jelenlétét ezeken az egyedeken (Sós-Koroknai V. pers. comm.).

A földikutyák az evolúcióbiológiától (Nevo 1991) a rákkutatás területéig (Gorbunova et al. 2012, Malik et al. 2016) számos kiemelt kutatási irány elsőszámú vizsgálati alanyai. A szántóföldi kultúrákban lévő földikutya-állományok megőrzése ezért tudományos szempontból kiemelkedő jelentőségü, hiszen ez az új típusú élőhely új lehetőségeket biztosít a földikutyák sokoldalú adaptációinak vizsgálatára.

\section{Természetvédelmi tapasztalatok}

A 2005 óta megtalált földikutya-állományok története természetvédelmi szempontból kétféleképpen alakult. Bizonyos élőhelyek - természetes jellegük, a rajtuk élő nagyszámú földikutya, valamint az ott megtalálható további jelentős természeti értékek miatt - országos védelemben részesültek (pl. Körös-éri Tájvédelmi Körzet, Bajai Földikutya Rezervátum Természetvédelmi Terület). A legtöbb állomány esetben viszont ilyenre nem került sor. Ez utóbbiak jellemzően települések szélén vagy belterületeken találhatóak, ami pedig merőben új szituáció az állami természetvédelem számára, és amelynek kezelése óriási kihívás. Érthetően nehezen kezelhetö probléma egy fokozottan védett emlősállat lakott területen belül található élőhellyel. Bár a földikutya fokozottan védett státusza elegendő biztosíték 
kellene, hogy legyen mind a példányok, mind az élőhelyek védelméhez is - hiszen a védett élő szervezetek életközösségének, vagy élőhelyének károsítása is büncselekmény (Büntető Törvénykönyvről szóló 2012. évi tv., XXIII. Fejezet, 242-243. $\S$ ) - általában olyan erős (gazdasági) érdekek jelentkeznek ezen élőhelyek hasznosítására, melyeket az állami természetvédelem csak nagy erőfeszítések árán, és sokszor így is csak ideig-óráig képes elhárítani. Mindezek alapján joggal merülhet fel az a vélemény, amely az utóbbi időben többször szakmai álláspontként is előkerült, hogy a szóban forgó állományok hosszabb távon nem megőrizhetőek. Ugyanakkor ezek az állományok pótolhatatlan értéket képviselnek, amenynyiben szeretnék a hazánk területén előforduló földikutya-fajokat hosszú távon is megőrizni. A probléma egy lehetséges megoldásként - már viszonylag korán - felmerült a földikutya-egyedek áttelepítésének lehetősége. Az eddig elvégzett földikutya-áttelepítések eredményeinek szakmai értékelése ugyanakkor számos tanulsággal szolgált. Nyilvánvalóvá vált például, hogy egy populáció teljes befogása és áttelepítése az eddig alkalmazott módszerekkel nem megvalósítható. Ráadásul, a monitorozások eredményei alapján a közvetlen veszélyhelyzet (havária) elhárítására, illetve veszélybe kerülő egyed kimentésére irányuló földikutya-áttelepítések közül egyetlen akció sem bizonyult sikeresnek (Ruzsa et al. 2020).

Az áttelepítési kísérletek mellett az elmúlt évek során komoly erőfeszítések történtek a megtalált földikutya-állományok eredeti élőhelyükön történő megőrzése érdekében is. A debreceni lucernaföld kapcsán történt intézkedések jól példázzák e lépések hatékonyságát. Az állomány megtalálását követően (illetve valamennyi későbbi, Hajdú-Bihar megyei töredékállomány előkerülése esetén is) a Hortobágyi Nemzeti Park Igazgatóság rögtön tájékoztatta a Hajdú-Bihar Megyei Kormányhivatal Környezetvédelmi és Természetvédelmi Főosztályát a fokozottan védett faj jelenlétéről, egyszersmind kérte korlátozás elrendelését az élőhelyre. Bár az elrendelt korlátozásokat a bíróságon többször is megtámadták, végül valamennyi fellebbviteli fórum helybenhagyta azokat. A korlátozások megtiltanak mindennemü talajbolygatással járó tevékenységet, valamint minden olyan beavatkozást, mely a földikutya-állományt veszélyezteti, és addig szólnak, amíg a fokozottan védett faj jelenléte kimutatható a területen. A korlátozásoknak köszönhetően sikerült több, az élőhelyek feldarabolódását, degradálódását vagy területének csökkenését okozó eseményt megakadályozni.

A különböző megyék kormányhivatalai ugyanakkor tapasztalataik, szakmai meggyőződésük vagy jogértelmezésük alapján eltérő gyakorlatot követhetnek. Egyes megyékben előfordult, hogy csupán a tulajdonosok és területhasználók tájékoztatására került sor, de korlátozást nem rendeltek el. Ismét más esetekben, az illetékes nemzeti park igazgatóságok nem is kezdeményeztek korlátozást. Mezőtúron például régóta ismert a földikutya belterületi jelenléte, azonban sosem rendeltek el korlátozást, csupán tájékoztatták a tulajdonosokat. A település köz- 
pontjához legközelebb fekvő élőhelyfolton a tulajdonosoknak már a populáció megtalálásakor érvényes építési engedélyeik voltak a terület hasznosítására. Tiltás hiányában egymást követően valósultak meg a beruházások a frissen azonosított földikutya-élőhelyen. Legelőször olyan helyrajzi számon került sor a beruházásra, melyről nem volt közvetlen földikutya-előfordulási adat. Az építkezéssel járó zavarás azonban elegendőnek bizonyult, hogy a szomszédos helyrajzi számokról is távozásra bírja a földikutyákat. Így elhárult az akadály a szomszédos területek beruházásai elől is. Mostanra az eredeti élőhely több mint fele beépült. A még megmaradt élőhely hasznosítására az elmúlt években támadt igény, a tulajdonos pedig a még ott élö földikutyák kitelepítéséért kezdett lobbizni. Ez a példa jól mutatja, hogy a természetvédelem határozott fellépése nélkül milyen sors vár a belterületen élö földikutya-állományokra. Természetesen ismertek olyan példák is, ahol korlátozás elrendelése nélkül is hosszú ideje fennmaradtak belterületi földikutya-állományok, az egyedszám drámai csökkenése vagy az élőhely degradálódása nélkül is. Ilyenek például Battonya belterületi földikutya-állományai.

A területhasználati korlátozás láthatóan nem az egyetlen módja a belterületi földikutya-állományok megóvásának, de az eddigi tapasztaltok alapján igen hasznos, jogszabály adta eszköz, melynek elrendelése biztosan javítja az adott állomány túlélési esélyeit.

\section{Megoldási javaslatok, jövöbeli lehetöségek}

$\mathrm{Az}$ eddigi tapasztalatok szerint a (városias környezetben fennmaradt) földikutya-állományok megőrzése szempontjából a védetté nyilvánítás jelent megfelelő módszert a populáció hosszú távú fennmaradásának biztosítására. Az áttelepítés viszont ezekben az esetekben a tapasztalatok alapján nem müködöképes alternatíva (Ruzsa et al. 2020). Ugyanakkor a városias környezetben fennmaradt állományok élöhelyén elrendelt területhasználati korlátozás hatékony jogi eszköznek bizonyult a populáció rövid-, illetve középtávú fennmaradásának biztosítására. Bár ez nyilvánvalóan nem jelent végleges megoldást, de szavatolni tudja az állomány biztonságát mindaddig, amíg a természetvédelmi szakemberek megnyugtató és kivitelezhető megoldást találnak a populáció megőrzésére. Az eddigi tapasztalatok alapján azonban az egyetlen valódi, hosszú távú megoldás az állományok élőhelyének jogi védelme. A legtöbb esetben az állami természetvédelem mindeddig ódzkodott a védetté nyilvánításoktól. A jelen cikkben tárgyalt állományok megőrzése ugyanakkor elengedhetetlen a földikutyák magyarországi fennmaradásának biztosításához. A természetvédelemtől elvárt szükségszerü célkitüzés pedig az, hogy valamennyi, természetes élőhelyek összehúzódásának és feldarabolódásának eredményeként visszamaradt területen előforduló, egykori természetes populáció maradványaként fennmaradt életképes állomány ,in situ” megőrzésére törekedjen. 
Fontos szakmai feladat azonban - és egyben kihívás is - az ökológiai csapdát jelentő élőhelyek kiszürése. Ezek a látszólagos élőhelyek ugyanis nem képesek hosszú távon biztosítani a földikutya-egyedek fennmaradását, rajtuk életképes populáció nem tud kialakulni. Természetes élőhely látszatát keltve azonban elég vonzóak a fiatal földikutyák számára, hogy az ott elpusztuló egyedek által megüresedett helyeken megtelepedjenek. Az ilyen területek esetében, az aktuálisan ott élő földikutya-egyedek befogását követően vagy a látszólagos élőhely felszámolásáról kell gondoskodni, vagy a földikutyák számára megközelíthetetlenné kell tenni a helyet. Az így befogott példányok elhelyezése ugyanakkor további problémát jelent. A legszerencsésebb megoldás az lehet, ha ezek az egyedek - a kérdés alapos szakmai vizsgálatát követően - egy már folyamatban lévő, új populáció létrehozására irányuló, természetvédelmi beavatkozásba bevonhatók.

A városias környezetben található földikutya-állományok élőhelyeinek helyes kezelése további kihívásokat is tartalmaz. Élöhelyeik fenntartása ugyanis sok esetben folyamatos emberi beavatkozást, kezelést igényel. Éppen ezért természetvédelmi szempontból szerencsés volna a szóban forgó állományok élőhelyének védetté nyilvánításán túl az élőhelyek állami tulajdonba és nemzeti parki vagyonkezelésbe kerülése is. Ezzel biztosítható lenne a földikutyák szempontjából szükséges, ám a tulajdonosok számára kötelező módon nem elöírható élőhelykezelési beavatkozások megvalósítása.

A bemutatott eredmények alapján a jövőben városias környezetben elökerülö földikutya-állományokat illetően a következő ajánlások fogalmazhatóak meg: Mindenképp szükséges az illetékes hatóság mielőbbi tájékoztatása a fokozottan védett faj jelenlétéről, ezzel együtt fontos kezdeményezni területhasználati, müvelési korlátozás elrendelését az érintett helyrajzi számokon. A szükséges élőhelyi és állományadatok összegyüjtése után, meggyőződve az élőhely fenntarthatóságáról és az állomány életképességéről (vagyis kizárva az ökológiai csapda lehetőségét), célszerü kezdeményezni az élőhely védetté nyilvánítását. Ezt követően, ha lehetőség nyílik rá, szerencsés lenne az élőhely állami tulajdonba vétele és nemzeti parki vagyonkezelésbe kerülése is. Így lehetne biztosítani, hogy az olykor természetvédelmi szempontból szokatlan helyeken előkerülő, ám kiemelkedő természeti értéket képviselő, a Kárpát-medence kevés ismert bennszülött emlősfaja közé tartozó magyarországi földikutyafajok hosszú távon is fennmaradhassanak.

Köszönetnyilvánitás - Köszönettel tartozunk a Hortobágyi, a Kiskunsági, a Körös-Maros és a Duna-Ipoly Nemzeti Park Igazgatóságok munkatársainak és a Magyar Természettudományi Múzeumnak, amiért munkánkat nem csupán lehetővé tették, de nagymértékben támogatták és segítették is. Külön köszönettel tartozunk dr. Csorba Gábornak, valamint a Fővárosi Állat- és Növénykert állatorvosainak, dr. Sós-Koroknai Viktoriának és dr. Sós Endrének szakértő közreműködésükért. A bemutatott munka és eredmények részben az 
Európai Unió LIFE17 IPE/HU/000018 számú pályázatának támogatásából megvalósuló „Grassland LIFE IP” projekt keretében jöttek létre.

\section{Irodalomjegyzék}

Bakker, J. P. (1989): Nature Management by Grazing and Cutting. On the Ecological Significance of Grazing and Cutting Regimes Applied to Restore Former Species-rich Grassland Communities in the Netherlands. - Kluwer Academic Publishers, Dordrecht, $400 \mathrm{p}$.

Biró, M., Bölöni, J. \& Molnár, Zs. (2018): Use of long-term data to evaluate loss and endangerment status of Natura 2000 habitats and effects of protected areas. - Conserv. Biol. 32: 660-671. https://doi.org/10.1111/cobi.13038

Boldog, G. (2010): Talajlakó emlösök túrásmorfológiai vizsgálata, különös tekintettel a nyugati földikutya (Spalax leucodon) természetvédelmi monitorozására. - Crisicum 6: 199-211.

Calhoun, J. B. (1962): Population density and social pathology. - Sci. Am. 206: 139-149.

Csorba, G., Krivek, G., Sendula, T., Homonnay Z. G., Hegyeli, Zs., Sugár, Sz., Farkas, J., Stojnić, N. \& Németh, A. (2015): How can scientific research change conservation priorities? - A review of decade-long research on blind mole rats (Rodentia: Spalacinae) in the Carpathian Basin. - Therya 6: 103-121. https://doi.org/10.12933/therya-15-245

Dobson, A. P. \& Hudson, P. J. (1986): Parasites, disease and the structure of ecological communities. - Trends Ecol. Evol. 1: 11-15. https://doi.org/10.1016/0169-5347(86)90060-1

Dudás, M. \& Lánszky, I. (1988): A földikutya újabb lelőhelye. - TermészetBúvár 53: 21.

Gorbunova, V., Hine, C., Tian, X., Ablaeva, J., Gudkov, A. V., Nevo, E. \& Seluanov, A. (2012): Cancer resistance in the blind mole rat is mediated by concerted necrotic cell death mechanism. Proc. Natl. Acad. Sci. U.S.A. 109: 19392-19396. https://doi.org/10.1073/pnas.1217211109

Hanski, I. (2011): Habitat loss, the dynamics of biodiversity, and a perspective on conservation. Ambio 40: 248-255. https://doi.org/10.1007/s13280-011-0147-3

Heth, G. (1991): Evidence of aboveground predation and age determination of the preyed, in subterranean mole-rats (Spalax ehrenbergi) in Israel. - Mammalia 55: 529-542. https://doi. org/10.1515/mamm.1991.55.4.529

Horváth, R. (2001): A Hortobágyi Nemzeti Park földikutya (Spalax leucodon) állományának vizsgálata. - Kutatási jelentés, $21 \mathrm{p}$.

Horváth, R., Bihari, Z., Németh, A. \& Csorba, G. (2007): Nyugati földikutya - In: Bihari, Z., Csorba, G. \& Heltai, M. (szerk.): Magyarország emlőseinek atlasza. Kossuth Kiadó, Budapest, pp. $157-159$.

Horváth, R. \& Vadnai, R. (2006): A földikutya. Szabolcs-Szatmár-Beregi Természet- és Környezetvédelmi Kulturális Értékőrző Alapítvány, Fehérgyarmat. 20 p.

Ives, A. R. (1992): Density-dependent and density-independent parasitoid aggregation in model host-parasitoid systems. - Am. Nat. 140: 912-937. https://doi.org/10.1086/285448

Judge, P. G. \& De Waal, F. B. (1997): Rhesus monkey behaviour under diverse population densities: coping with long-term crowding. - Anim. Behav. 54: 643-662. https://doi.org/10.1006/ anbe.1997.0469

Knell, R. J. (2009): Population density and the evolution of male aggression. - J. Zool. 278: 83-90. https://doi.org/10.1111/j.1469-7998.2009.00566.x

Malik, A., Domankevich, V., Lijuan, H., Xiaodong, F., Korol, A., Avivi, A. \& Shams, I. (2016): Genome maintenance and bioenergetics of the long-lived hypoxia-tolerant and cancer-resistant 
blind mole rat, Spalax: a cross-species analysis of brain transcriptome. - Sci. Rep. 6: 38624 . https://doi.org/10.1038/srep38624

Moldován, O. (2014): Az erdélyi földikutya Nannospalax (leucodon) transsylvanicus új populációjának létrehozása és az első év tapasztalatai. - Diplomamunka, Debreceni Egyetem, Debrecen, $44 \mathrm{p}$.

Németh, A. (2011): A kárpát-medencei földikutyák (Rodentia: Spalacinae) rendszertana, elterjedése és természetvédelmi helyzete. - Doktori értekezés. Eötvös Loránd Tudományegyetem, Budapest. $136 \mathrm{p}$.

Németh, A. \& Csorba, G. (2014): Morfológia, genetika és ös-környezettan - 100 év kutatásai a Kárpát-medence endemikus rágcsálócsoportján. - Magyar Tudomány 175: 432-436.

Németh, A., Révay, T., Hegyeli, Zs., Farkas, J., Czabán, D., Rózsás, A. \& Csorba, G. (2009): Chromosomal forms and risk assessment of Nannospalax (superspecies leucodon) (Mammalia: Rodentia) in the Carpathian Basin. - Folia Zool. 58: 349-361.

Németh, A., Farkas, J., Krnács, Gy. \& Csorba, G. (2010): KvVM Fajmegörzési tervek: Nyugati földikutya (Nannospalax leucodon). - KvVM Természetvédelmi Szakállamtitkárság, Budapest. 31 p.

Németh, A., Csorba, G., Farkas, J., Krnács, Gy., Molnár, A., Boldogh, G. \& Szelényi, B. (2013a): VM Fajmegörzési tervek: Kárpát-medencei Nyugati földikutya kisfajok (Nannospalax [superspecies leucodon]). - VM Környezetügyért Felelős Államtitkárság, Budapest. 68 p. https://doi. org/10.13140/RG2.2.25180.59529

Németh, A., Krnács, Gy., Krizsik, V., Révay, T., Czabán, D., Stojnic, N., Farkas, J. \& Csorba, G. (2013b): European rodent on the edge: status and distribution of the Vojvodina blind mole rat. SpringerPlus 2: 2. https://doi.org/10.1186/2193-1801-2-2

Németh, A., Hegyeli, Zs., Sendula, T., Horváth, M. \& Csorba, G. (2016): Danger underground and in the open - predation on blind mole rats (Rodentia: Spalacinae) revisited. - Mammal Rev. 46: 204-214. https://doi.org/10.1111/mam.12062

Németh, A., Bárány, A., Csorba, G., Magyari, E., Pazonyi, P. \& Pálfy, J. (2017): Holocene mammal extinctions in the Carpathian Basin: a review. - Mammal Rev. 47: 38-52. https://doi.org/10.1111/ mam. 12075

Németh, A., Sramkó, G., Csorba, G., Czabán, D., Hegyeli, Zs. \& Cserkész, T. (2018): „Fogas vakony, földi kölök és háromövű csíkosegér" Molekuláris diverzitás és endemikus emlősfajok a Kárpát-medencében - In: Tardy J. \& Dévai Gy. (szerk.): A biodiverzitásról másképp. Magyar Természettudományi Társulat, Budapest, pp. 138-148.

Nevo, E. (1991): The subterranean mole rats (Spalax ehrenbergi superspecies) in Israel as an evolutionary model of active speciation and adaptive radiation. - Isr. J. Zool. 37: 174-175.

Newbold, T., Hudson, L. N., Hill, S. L., Contu, S., Lysenko, I., Senior, R. A., Börger, L., Bennett, D. J., Choimes, A., Collen, B., Day, J., De Palma, A., Díaz, S., Echeverria-Londoño, S., Edgar, M. J., Feldman, A., Garon, M., Harrison, M. L. K., Alhusseini, T., Ingram, D. J., Itescu, Y., Kattge, J., Kemp, V., Kirkpatrick, L., Kleyer, M., Correia, D. L. P., Martin, C. D., Meiri, S., Novosolov, M., Pan, Y., Phillips, H. R. P., Purves, D. W., Robinson, A., Simpson, J., Tuck, S. L., Weiher, E., White, H. J., Ewers, R. M., Mace, G. M., Scharlemann J. P. W. \& Purvis A. (2015): Global effects of land use on local terrestrial biodiversity. - Nature, 520: 45-50. https://doi.org/10.1038/ $\underline{\text { nature } 14324}$

Poschlod, P. \& Bonn, S. (1998): Changing dispersal processes in the central European landscape since the last ice age: an explanation for the actual decrease of plant species richness in different habitats? - Acta Bot. Neerl. 47: 27-44.

QGIS Development Team (2013): QGIS Geographic Information System. - Open Source Geospatial Foundation Project. http://qgis.osgeo.org 
Rakonczay, Z. (szerk.) (1989): Vörös Könyv: a Magyarországon kipusztult és veszélyeztetett növény-és állatfajok. - Akadémiai Kiadó, Budapest, $360 \mathrm{p}$.

Ruzsa, J., Schneider, V., Farkas, J. \& Németh A. (2020): A magyarországi földikutya (Rodentia: Spalacinae) áttelepítések értékelése - Termvéd Közlem. 26:70-92. https://doi.org/10.20332/tvkinatconserv.2020.26.70

Schneider, V., Ruzsa, J., Czabán, D. \& Németh A. (2019): Egy földikutya-áttelepítés tanulságai. Termvéd Közlem. 25: 14-33. https://doi.org/10.20332/tvk-jnatconserv.2019.25.14

Sterbetz, I. (2002): Földikutya (Microspalax leucodon, Nordmann 1840) előfordulások a DélkeletAlföldröl. - A Békés Megyei Múzeumok Közleményei 23:17-22.

Topachevskii, V. A. 1969: Fauna of the USSR: Mammals. Mole rats, Spalacidae. - Smithsonian Institution and the National Science Foundation, Washington.

Vásárhelyi, I. (1926): Adatok a földikutya (Spalax hungaricus hungaricus Nhrg.) életmódjának ismeretéhez. - Állattani Közlem. 23:169-226.

Vásárhelyi, I. (1930): A vakondok vára és a kószapocok fészke. - Állattani Közlem. 27: 173-181.

Vidacs, J. A., Farkas, J. \& Németh, A. (2013): Konvergenciák, divergenciák és adaptáció a talajlakó életmódot folytató emlősöknél. - Állattani Közlem. 98:21-46.

Hivatkozott jogszabályok

2012. évi C. törvény a Büntető Törvénykönyvröl, XXIII. Fejezet: A Környezet és a Természet Elleni Büncselekmények, 242-243.§ Természetkárosítás.

Internetes térképforrások

http1: I. Katonai Felmérés (1782-85): HM Hadtörténeti Intézet és Múzeum Térképtára, Arcanum Adatbázis Kft., Budapest. http://mapire.eu/hu/map/firstsurvey/

http2: II. Katonai Felmérés (1806-1869): HM Hadtörténeti Intézet és Múzeum Térképtára, Arcanum Adatbázis Kft., Budapest. http://mapire.eu/hu/map/secondsurvey/

http3: III. Katonai Felmérés (1869-1887): HM Hadtörténeti Intézet és Múzeum Térképtára, Arcanum Adatbázis Kft., Budapest. http://mapire.eu/hu/map/thirdsurvey25000/

http4: II. Világháborús Katonai Felmérés (1941): HM Hadtörténeti Intézet és Múzeum Térképtára, Arcanum Adatbázis Kft., Budapest. http://mapire.eu/hu/map/hungary1941/

http5: 1959- 2007 időszakból származó légifelvételek: Digitális légifelvétel archívum, Lechner Nonprofit Kft. légifilmtára (FÖMI, Budapest) https:/www.fentrol.hu/hu/ 


\title{
Do they always stand in the way? - Challenges of blind mole rat protection in urban environments in Hungary
}

\author{
Attila Németh ${ }^{1,2}$, Orsolya Moldován ${ }^{3} \&$ László Szél $^{3}$ \\ ${ }^{1}$ BirdLife Hungary - Hungarian Ornithological and Nature Conservation Society, \\ H-1121 Budapest, Költö u. 21., Hungary \\ ${ }^{2}$ Hungarian Natural History Museum, H-1088 Budapest, Baross u. 13., Hungary \\ ${ }^{3}$ Hortobágy National Park Directorate, H-4024 Debrecen, Sumen u. 2 , Hungary \\ E-mail:dr.attila.nemeth@gmail.com
}

Endemic rodents belonging to the lesser blind mole rat (Nannospalax (superspecies leucodon)) species complex are among the most endangered mammals in Hungary. They have suffered a dramatic and rapid population decline over the past fifty years, thus their current distribution and the number of the remaining localities are not exactly known. Finding previously unknown but still existing populations in Hungary is a current task for the conservation professionals. However, the discovery of such previously unknown populations often causes situations that are unusual and difficult to manage for nature conservation, as they are typically located in territories not under protection, rather in places of investment, development, construction or agricultural use. Here we present the previously unknown populations found in Hungary over the last decade, as well as the problems and challenges caused by the conservation of those localities. The conservation efforts made so far, the applied solutions and the lessons we learned may contribute to successful nature conservation management of other species or similarly sensitive situations.

Keywords: Nannospalax (superspecies leucodon), distribution mapping, population size estimation, monitoring, habitat requirements 